\title{
Transatlantica
}

Revue d'études américaines. American Studies Journal

$2 \mid 2018$

Les mots pour le dire. Vocabulaire politique et propagande dans une perspective transatlantique

\section{Reenchanting Urban Wildness: To Perceive, Think and Live With Nature in its Urban Environment}

University of Perpignan Via Domitia, June 5-8, 2019

Noémie Moutel and Caroline Granger

\section{OpenEdition}

Journals

\section{Electronic version}

URL: https://journals.openedition.org/transatlantica/13550

DOI: $10.4000 /$ transatlantica. 13550

ISSN: $1765-2766$

Publisher

Association française d'Etudes Américaines (AFEA)

\section{Electronic reference}

Noémie Moutel and Caroline Granger, "Reenchanting Urban Wildness: To Perceive, Think and Live

With Nature in its Urban Environment", Transatlantica [Online], 2 | 2018, Online since 01 February 2020, connection on 06 February 2023. URL: http://journals.openedition.org/transatlantica/13550 ; DOI:

https://doi.org/10.4000/transatlantica.13550

This text was automatically generated on 6 February 2023

\section{(c) (†) $\odot$}

Creative Commons - Attribution-NonCommercial-NoDerivatives 4.0 International - CC BY-NC-ND 4.0

https://creativecommons.org/licenses/by-nc-nd/4.0/ 


\section{Reenchanting Urban Wildness: To Perceive, Think and Live With Nature in its Urban Environment}

University of Perpignan Via Domitia, June 5-8, 2019

\section{Noémie Moutel and Caroline Granger}

This second edition of the International Conference on Ecopoetics organized by Bénédicte Meillon, under the aegis of the research center CRESEM (Centre de Recherche sur les Sociétés et Environnements en Méditerranée) of the University of Perpignan Via Domitia, explored the literary and social manifestations of diverse interactions linking humans and non-humans in the midst of an expanding urbanization. The conference gathered a hundred scholars, novelists, poets, sociologists, ethnologists, teachers, dancers and choreographers, who addressed the artistic, intellectual and pedagogical means of promoting a biocentric view of the world. The communications, arranged in thematic panels, contributed to revealing how written words and ecologically-minded practices and research can inspire us to reenchant the urban wildness whilst outlining possible futures. This four-day conference allowed for transdisciplinary and international encounters of all kinds: choreographers, landscape designers, secondary school teachers, PhD students, university professors, as well as researchers in linguistics, literature, sociology, philosophy, arts and science joined to contemplate the manifold possibilities of ecopoetical approaches. This report shall focus on contributions that dealt specifically with North American research and matters of transatlantic humanities. 


\title{
Reenchanting ruins, industrial wastelands, and urban voids
}

\author{
Margaux Le Donné (Institut d'Études Politiques de Paris, France), \\ “From 'Green-Cities' to the Reappropriation of Our 'Ruined-Cities'”
}

2 Margaux Le Donné opened her talk by drawing a distinction between 'green-cities' where green-washing rules, and streets, businesses, housing and infrastructures are only accessible to middle and upper classes - and 'ruined-cities,' where nature and culture are physically and culturally imbricated. The question of wildness in urban spaces requires to take into account what Le Donné called "a grammar of sharp and complex ecological struggles". To renegociate the definition of Progress that greencities are paradigmatically based upon, Le Donné relied on anthropologist Anna Lowenhaupt Tsing's recent work, The Mushroom at the End of the World (2015). Prefaced in its French version by philosopher Isabelle Stengers, Tsing's work is an exploration of the rhizomatic ethnic, social, commercial and biological interactions that link the matsutake mushroom to the "possibility of living on the ruins of capitalism". Le Donné draws on her work to reinvest the notion of ruins with an unsettling ambiguity: ruins appear where capitalism has cut humans and non-humans from their ecosystemic roots, turning their inhabitants into 'mobile capital goods'. In that sense, cities are ruins, already precarious and unstable urban settings. Le Donné thus concluded that to consider cities as 'urban-ruins' can lead to our noticing an ongoing "ecology of perturbation," where interstices and cracks allow for spaces of resistance to the capitalist exploitation of human and non-human lives.

\section{Reenchanting urban wildness through climate-fiction and science-fiction}

\author{
Claire Perrin (Université de Perpignan Via Domitia, France), \\ "Starhawk's San Francisco in The Fifth Sacred Thing: A \\ Reenchantment Utopia"
}

3 In The Fifth Sacred Thing (1993), Starhawk imagined an initiation narrative for both her readers and her main protagonists, Madrone and Bird, in a Californian landscape almost entirely taken over by the rule of the Stewards, a group of conservative fundamentalist white men. Claire Perrin analyzed how San Francisco, free from the hold of the Stewards, becomes the setting of applied ecofeminist ethics and practices. The permacultural and collective modes of subsistence and organization chosen by the city's inhabitants present a working critique of the Stewards' society, based on patriarchal and capitalistic values. As opposed to a constant exploitation of nature, a privatization of resources, a subjectivation of women, and the mandatory cult to a single male deity, the people of San Francisco declare sacred and inalienable the free sharing of all resources related to the four elements: air, water, fire and earth. According to Perrin, urban wildness is reenchanted by the protagonists' willful adaptation to climate changes. She coined this system "a social functioning with nature," where liberation and autonomy are ethically and pragmatically related to the 
San Franciscans' reclaiming of agricultural practices and knowledge. The growing field of ecofeminist research provides a critical framework to address this novel, as it helps to think ecology and gender relations combined. Indeed, the San Franciscan organic community puts into practice collective decision-making tools in line with feminist analysis of patriarchal society. Grassroots political activism is thus directly linked to ecological preservation of one's habitat and to transformative feminist politics. Perrin further noted and concluded by stating that The Fifth Sacred Thing deviates significantly from the majority of cli-fi novels as it counters pessimistic stereotypes with ecofeminist and revolutionary pathways.

\section{Joachim Zemmour (Université d'Angers, France), “Men-Flowers and Women-Flowers in the Ecopoetic Works of Clark Asthon Smith: When Sci-Fi/Fantasy Literature Takes a Visionary Look at the Future"}

4 Joachim Zemmour introduced his audience to the works of Clark Ashton Smith, Californian poet and short-fiction writer, as well as "one of the founding fathers of the modern sci-fi/fantasy genre," along with his contemporary H.P. Lovecraft. C.A. Smith's relevance to the ecopoetical topic of "reenchanting urban wildness" lies in his early ability to challenge anthropocentric and anthropomorphic assumptions through fictional narratives. Zemmour's presentation drew attention to the recent Penguin Classics publication of collected stories and poems by C.A. Smith, The Dark Eidolon and other fantasies (2014), and to his recent translation of The City of the Singing Flame (La Flamme Chantante, Actes Sud: 2013). He asserted that the author should be counted as a "true ecopoet, and not as a minor writer of some 'subgenre". Zemmour first explained that C. A. Smith's story The Demon and the Flower [1933] blurred the limits between human, animal and vegetal reigns. Through the symbolic shape-shifting of a human character into a plant, notions of hybridity and trans-speciesism were brought to light and further expanded upon. The Maze of the Enchanter [1932] was the second story under study. It takes place in a "utopian garden-city" where "man-made buildings become a shrine of Nature". There, flowers are depicted as highly sexual, sentient and potentially malevolent creatures. Humans undergo transformation through interaction with them. Zemmour finally claimed that the ultimate ecopoetic movement occurs through the writer's words, via the dreamscapes thus drawn, for which fantasy/sci-fi literature appears to be a most favorable genre.

\section{Ecopoetry of survivance and postcolonial hybridity}

\section{Katherine Lynes (Union College, USA), "'How on Earth Do You Read Me': Stepping Outdoors in Haryette Mullen's Urban Tumbleweed"}

In her presentation, Katherine Lynes introduced and discussed Haryette Mullen's latest poetry collection, Urban Tumbleweed: Notes from a Tanka Diary (2013). It is composed of 366 tankas, written on the occasion of her daily walks in Los Angeles. Lynes explained that tankas are short poetic forms composed of 31 syllables, which Mullen chose to lay out in three lines, one building up to the next. Lynes argued that Mullen's poetry, through "the brevity and clarity of tanka," reaches readers in need of reconfiguring 
what nature signifies in urban spaces. Mullen indeed writes ecocritical poetry dealing with how nature resides, or survives, in cities, evoking urban encounters with the nonhuman that shift the outlines of the urban landscape.

Though they can't help flaunting their

vulnerability, I imagine that creeping snails

are trusting me to spare their fragile shells.

As in this tanka, Mullen's poetry draws attention to the borders created between desirable and undesirable nature. The city-dweller's footsteps might cross paths with that of a snail, and in that incident, daily actions are brought to attention, and placed in relation to the whole. In that sense, Katherine Lynes argued that Mullen's work makes ordinary urban earth extraordinary.

\section{Karen Houle (University of Guelph, Canada) and David Lloyd (Le Moyne College, USA), "Poetry Readings with Commentary”}

6 In this panel, poets Karen Houle and David Lloyd invited the audience to take their seats in a circular setting, one poet facing the other across the circle. Each introduced their work, and their relation to poetry, prior to reading out of their most recent publications. Karen Houle described the circumstances in which her book, Grand River Watershed: A Folk Ecology (2018), emerged. Resident writer at North House, a leadingedge sustainable habitation on the Grand River Watershed in southern Ontario, Houle met with gardeners, educators, farmers, artists, botanists, ecologists, geologists, archaeologists, and historians of the area. She then undertook to creatively merge the gleaned geological, climatic, historical, and ecosytemical narratives, thus attempting to chronicle "the existence of a particular watercourse over the passage of time".

David Thomas Lloyd offered poems pertaining to elements of nature familiar to humans dwelling in urban and suburban areas: thistles, hawks, house wrens, goldfinches... Reading from his latest poetry collection, The Everyday Apocalypse (2018), and from other sources, Lloyd performed poems entitled "Forgotten," "Sovereign," and "Hawk in the City," all sharing a celebratory mode of mindful contemplation. The ensuing conversation entertained the idea that ecopoetry could be understood as a way, for a writer, not to focus so much on the self as on the self in relation with other lives, sensations and stories.

\section{Ecopoetics of movement}

\section{Caroline Granger (Université de Caen Normandie, France), "An Event by Merce Cunningham: Experiencing an Unexpected Landscape"}

Merce Cunningham died on July 26th, 2009. Some days later, the dancers of his company decided to honor him by performing an Event in Battery Park, at the southern tip of Manhattan. The creative process of this work gave another existence to the choreographies and was a way for the audience to have a unique experience in an unusual space. Viewers stood or sat among buildings and natural elements to attend this performance based upon fragments new and old, chosen through chance procedures. 
9 According to Caroline Granger, Merce Cunningham wished to share his memories and observations of different independent structures in natural landscapes and more especially in forests where trees, leaves, mushrooms, ants or birds live together. The choreographer questioned the viewers' relationships to the wilderness without representing its elements, only the structures of different movements happening unexpectedly in a shared space.

\section{Keynote and performances}

\section{Serenella lovino (University of North Carolina, USA), "The Invisible Wild: Dilemmas and Resources of the Anthropocene Gardens"}

10 The talk began with photographs showing works created by the American female artist Tamiko Thiel. Her process links the so-called material and virtual worlds: using smartphones or tablets in an urban landscape, viewers can discover hidden digital gardens before their eyes. In this augmented virtual reality, plants appear as mutants of different shapes and colors.

11 Serenella Iovino questioned the presence of these new virtual layers in the topography of the Anthropocene. Through cables, wires, satellites and networks, a complex landscape is built between electronic devices and the natural environment. Referring to artistic works, she invited the audience to change its perception and think about this garden. What are its necessary conditions to exist? The fact that this "augmented reality garden" first takes roots in the living soil, and that the technology that allows its visibility was produced in terrible working conditions cannot be denied. Art broadens people's mind, and also reveals the ghosts living behind technology. The challenge is to weave these two environments, the technological and the wild, to create what Gilles Clément calls "gardens of resistance". In her conclusion, Serenella Iovino mentioned the Parco Arte Vivente in Turin as an oasis where such a tour de force is achieved.

\section{Bilingual Ecopoetics Performance on Climate Change Based on the IPCC Report, by Nathalie Blanc (CNRS and Université Paris Diderot, Paris, France) and Clara Breteau (Université de Tours, France)}

12 As an evening performance, researchers Clara Breateau (philosopher, economist, permaculturist) and Nathalie Blanc (research supervisor in urban wilderness and environmental aesthetics at the CNRS) echoed each other's voices, and gave new depth to the latest IPCC report. Published in November 2018 by the Intergovernmental Panel on Climate Change, the report is a scientific, factual and objective assessment of the causes and consequences of climate deregulation around the globe. First talking one after the other, Breteau using the English version of the report, and Blanc working from an original French translation (the report does not officially exist in any other language than English so far), they gradually let their voices overlap, echo and even interfere with one another. The intensity and complexity of the ongoing ecological changes were thus rendered audible and sensitively perceivable by the captivated audience. 
13 Although many contributors were French, or, as indicated here, coming from North America, it should be noted that the conference drew participation from researchers of Spain, Russia, Turkey, Italy, Belgium, England, Finland, India, Poland, and Switzerland. They brought many more themes to the discussion such as: "Cultural Animals and Urban Zoopoetics," "Arts and Environmental Education," "Urban Wilderness and Urban Design," "Decolonial and Ecofeminist Ecopoetics," "Contemporary Dance and Ecopoetic Movement," "Material Imagination of the Environment through Urban Art," and “Indigenous Reclaiming of Enchanting Naturecultures".

INDEX

Subjects: Actualité de la recherche

\section{AUTHORS}

\section{NOÉMIE MOUTEL}

Université de Caen-Normandie

CAROLINE GRANGER

Université de Caen-Normandie 